\title{
Development and assessment of acceptability and nutritional properties of a light snack
} Desenvolvimento e avaliação da aceitabilidade e das propriedades nutricionais de um snack light

\author{
Vanessa Dias CAPRILES ${ }^{1}$, Rosana Aparecida Manólio SOARES ${ }^{1}$, José Alfredo Gomes ARÊAS ${ }^{1 *}$
}

\begin{abstract}
A light snack was developed using a fat replacer as a flavor fixative agent. The product presented a calorie reduction of up to $47.5 \%$ in comparison with products available on the market. The impact of this fat replacer on the sensory properties was determined by comparing this light snack to the traditional ones. No significant difference in texture was observed; however, there was a difference in color $(\Delta \mathrm{E}=8.67)$, due mainly to luminosity $(\Delta \mathrm{L}=7.79$ ). The light snack presented high sensory acceptability $(7.27 \pm 1.3 ; 82.5 \%$ of grades were $\geq 7$ on 9 -point hedonic scale); no significant difference in snack acceptability was observed. However, the traditional snack was significantly preferred in sensory terms $(p<0.05)$. In an opinion survey when the consumers were informed about snack composition, $75 \%$ of them said that they would buy the light snack instead of the traditional one. The caloric and fat reductions allow the use of the claims "light snack" and "fat free", in accordance with the legislation of various countries. We conclude that it is technologically possible to use a fat replacer in snack production, resulting in a sensory acceptable light snack with great potential to replace traditional ones.

Keywords: light snack; fat replacer; consumer acceptance; food extrusion.
\end{abstract}

\section{Resumo}

O snack light foi desenvolvido através do uso de um substituto de gordura como veículo de aromatização, gerando um novo produto com redução calórica de até $47,5 \%$ em relação aos comercializados. Avaliou-se o impacto desta substituição nas características sensoriais do produto, através da comparação com um snack convencional. Não foi observada diferença significativa de textura. Foi observada diferença de cor $(\Delta \mathrm{E}=8,67)$, principalmente devido à luminosidade $(\Delta \mathrm{L}=7,79)$. O snack light apresentou elevada aceitabilidade sensorial $(7,27 \pm$ 1,$3 ; 82,5 \%$ das notas foram $\geq 7$ em uma escala hedônica de 1 a 9) e não houve diferença significativa de aceitação entre os snacks. Porém, o produto convencional foi significativamente preferido em relação ao light ( $\mathrm{p}<0,05$ ). Em uma pesquisa de opinião, $75 \%$ dos entrevistados, ao serem informados de sua composição, afirmaram que comprariam o snack light ao invés do convencional. A redução calórica e do teor de lipídios permite o uso das alegações snack light e isento de gordura, de acordo com a Legislação de vários países. Conclui-se que a utilização de substitutos de gordura na fabricação de snacks é tecnologicamente viável, resultando em um novo produto aceito sensorialmente e com grande potencial para substituir os tradicionais.

Palavras-chave: snack light; substituto de gordura; aceitabilidade sensorial; extrusão termoplástica.

\section{Introduction}

Snacks are ready-to-eat products obtained by extrusion of grits from germ-free maize. Extrusion is a process in which food material is forced to flow under a variety of conditions of mixing, heating and shear using a die. When heating and working during the extrusion process, the macromolecules in food ingredients lose their native, organized tertiary structure and form a viscous plasticized material. At the end of the die, fast vaporization of the water present in food takes place, leading to structural reorganization and producing a series of textured products. Food extrusion is widely used to restructure starch and protein-based materials, thus enabling to manufacture a variety of textured convenience foods. Among these, snacks are the main product made by extrusion ${ }^{5,6,8,17,18,22,23,24}$.

For snacks to be acceptable for consumption, they are normally flavored by external application of flavor, using hydrogenated vegetable fat as an agent for fixing flavors onto the surface of the extrudates. This method of flavoring gives rise to the main nutritional disadvantage of these products because hydrogenated vegetable fat contains high amounts of saturated and trans fatty acids. Snacks available on the market

Recebido para publicação em 22/8/2006

Aceito para publicação em 18/7/2007 (001826)

Departamento de Nutrição, Faculdade de Saúde Pública,

Universidade de São Paulo - USP, Av. Dr. Arnaldo, 715, CEP 01246-904,

São Paulo - SP, Brasil,

E-mail: jagareas@usp.br

*A quem a correspondência deve ser enviada in various countries present $13.6-50.0 \%$ of saturated fatty acids and $0.0-30.4 \%$ of trans fatty acids ${ }^{14,27}$.

It has become known that a high intake of saturated fat contributes to the development of coronary heart diseases. More recently, trans fatty acids have also been associated with the risk of these diseases. Many studies have shown that a high intake of trans fatty acids has more severe effects than does the consumption of saturated fatty acids, thereby increasing LDL-cholesterol levels and simultaneously decreasing HDL-cholesterol levels, and also increasing the risk of cancer. ${ }^{1,7,12,20,26}$.

The present study investigated the development of a new snack by means of replacing hydrogenated vegetable fat by a fat replacer as a flavor fixative agent. The impact of fat replacement on the sensory and nutritional properties was determined by comparing the snack that was developed to the traditional one.

\section{Materials and methods}

\subsection{Snack production}

Snacks were made in a single-screw extruder (L/D ratio 20) with a production capacity of $25 \mathrm{~kg}$ per hour and four heating zones (RXPQ Labor 24 - INBRAMAQ, Indústria de Máquinas Ltda, Ribeirão Preto, S.P., Brazil). Germ-free maize flour (Zea mays L.) with moisture adjusted to $15 \%$ was used. 
The following conditions were set on the basis of preliminary experiments: $210 \mathrm{rpm}$ screw rotation, 1:1 screw compression ratio. Temperature profiles were kept constant in the feed zone at $50{ }^{\circ} \mathrm{C}$, in the compression-metering zone at $75{ }^{\circ} \mathrm{C}$ and in the die at $130{ }^{\circ} \mathrm{C}$. The extruded products were cut using a face cutter as they left the extrusion die.

Snacks presented an expansion ratio of around 6 and a cylindrical format. The expansion ratio was determined as the ratio of the extruded product diameter to the diameter of the die hole, both measured using a caliper rule. The value reported was the average of 30 measurements.

The feasibility of using the fat replacer as a snack-flavoring vehicle was tested earlier using a solution containing salt, flavor, fat replacer and water. Milk serum protein concentrate, guar gum, xanthan gum and modified starch were used for preliminary tests, as there is no specific fat replacer for snack flavoring. Among the products tested, hydrocolloids allowed complete particle aggregation to the snack surface. Moreover, it was observed in previous work ${ }^{10}$ that the higher the amount of solution spread in the snacks, the higher its shear strength. This probably occurred because of volume reduction and formation of a rind consisting of flavor salt and fat replacer over the product surface after drying, thereby promoting complete solid particle aggregation to the snack surface. In this previous work, modified starch flavoring solution proved to be the most adequate vehicle for snack flavoring, causing fewer changes in product volume and texture than the other fat replacers tested ${ }^{10}$.

Therefore, modified starch became the target of a deeper investigation by our group. CAPRILES, SOARES, AREAS ${ }^{11}$ tested the response surface methodology to optimize the flavoring solution composition for minimum changes in snack volume and shear strength. However, none of the linear, second order or interaction effects of the salt and modified starch content were significant. Based on these previous tests, a flavoring solution consisting of $4 \%$ bacon flavor, $2 \%$ salt and $1 \%$ modified starch ( $60 \%$ solids and $40 \%$ water) was chosen in the present study as the appropriate formulation, as it caused the minimum change in volume $(0.4 \%)$ and texture $(0.2 \%)$.

External application of flavor was done in a coating pan (AIR 400 - Erweka, Heusenstamm, Germany) by aspersion of a solution containing water, modified starch (N-Tack, National Starch \& Chemical Industrial Ltda., Brazil), bacon flavor (Raí Ingredients Comercial Ltda., Brazil) and salt (Norte Salineira S.A. - Indústria e Comércio, Brazil). The snack flavoring process consisted of spraying the solution over the snacks, mixing and drying. For the latter, air heated to $80{ }^{\circ} \mathrm{C}$ was applied for one minute for each $100 \mathrm{~g}$ of snack.

The proximate composition, instrumental color and texture parameters and sensory acceptability of the new snack were assessed and compared to a traditional one which was obtained by adding $22 \%$ hydrogenated vegetable fat onto the surface of the extrudates. Both snacks were produced under the same extrusion conditions and presented the same amounts of flavor (4\%) and salt ( $2 \%$ ), which are the usual salt and flavor concentrations used by snack manufacturers, and thus differing only in the fixative agent for the flavors.

\subsection{Proximate composition}

The following methods were used: desiccation at $105{ }^{\circ} \mathrm{C}$ for moisture; calcination at $550{ }^{\circ} \mathrm{C}$ for ash; and micro Kjeldahl $(\mathrm{N} \times 6.25)$ for protein $^{2}$. Lipid extraction was done by a dry column method in accordance with MARMER and MAXWELL ${ }^{21}$. Carbohydrate content was estimated by difference. The values reported were averages of three measurements. Caloric value was estimated by means of ATWATER coefficients: $4 \mathrm{kcal} . \mathrm{g}^{-1}$ for proteins, 4 kcal.g ${ }^{-1}$ for carbohydrates and 9 kcal.g ${ }^{-1}$ for lipids ${ }^{28}$.

\subsection{Nutritional composition of snacks available on the market}

To compare the new product with snacks available on the market, samples of 11 products were acquired from supermarkets in the city of São Paulo. The nutritional values shown on product labels were used.

\subsection{Fatty acid composition}

Ten grams of milled snacks were used to analyse the fatty acid composition. The same procedure was adopted for snacks available on the market and for the product that was developed. An extract aliquot containing $50 \mathrm{mg}$ of lipids, obtained by a dry column method in accordance with MARMER and MAXWELL ${ }^{21}$, was collected and fatty acid esterification was carried out in accordance with the method developed by HARTMAN and LAGO ${ }^{19}$. Fatty acid methyl esters were diluted to about $1 \%$ with hexane and $1 \mu \mathrm{L}$ of this solution was injected into a gas chromatograph (Chrompack CP9002) equipped with a fused silica capillary column (CP-Sil 88; $50 \mathrm{~m} \times 0.25 \mathrm{~mm}$ and $0.2 \mu \mathrm{m}$ id).

The carrier gas was hydrogen (flow $1.5 \mathrm{~mL} \cdot \mathrm{min}^{-1}$ ) with a split injection of 1:70. The injector temperature was set at $270{ }^{\circ} \mathrm{C}$; the oven temperature profile was: $100^{\circ} \mathrm{C}$ for 2 minutes and then increasing at a rate of $5{ }^{\circ} \mathrm{C} \cdot \mathrm{min}^{-1}$ (for 28 minutes) to a final temperature of $240{ }^{\circ} \mathrm{C}$; the flame ionization detector temperature was set at $300{ }^{\circ} \mathrm{C}$. The fatty acid methyl esters were identified by comparing the retention times with those of standard Sigma Aldrich 189-19 (Fatty acid methyl ester mixture). The cis/trans linoleic and linolenic fatty acid isomers were identified by comparing standards according to the recommended practice (AOCS Ch 2a-94) ${ }^{3}$ and the official method (AOCS Ce 1f-96) $)^{4}$. These techniques, as well as the one used in the present study did not separate the C18:3 ctc/tcc isomers. The standards used were Sigma Aldrich L8404 (Linoleic acid methyl ester cis/trans isomers) and L6034 (Linolenic acid methyl ester, isomer mix). The amount of each component was calculated by an area normalization method.

\subsection{Shear strength analysis}

The shear strength of the snacks was determined as the maximum force offered by the sample during shearing in a texture-testing machine (TAXT2i - TA Instruments, England) 
equipped with a Warner-Bratzler device. The crosshead speed was $1 \mathrm{~mm} . \mathrm{s}^{-1}$ and the values reported were averages of 15 determinations.

\subsection{Color measurement}

Color was evaluated by the CIE L*a*b* system (Color Quest XE - Hunter Lab, USA). Luminosity ( $\left.L^{*}\right)$, red-green color opposition ( $\mathrm{a}^{*}$ ) and blue-yellow opposition ( $\left.\mathrm{b}^{*}\right)$ were determined and the total color difference between the traditional and the developed snacks, $\Delta \mathrm{E}$, was calculated as follows ${ }^{15}$;

$$
\begin{aligned}
& \Delta \mathrm{E}=\left[\Delta \mathrm{L}^{* 2}+\Delta \mathrm{a}^{* 2}+\Delta \mathrm{b}^{* 2}\right]^{1 / 2} \\
& \Delta \mathrm{L}^{*}=\mathrm{L}_{1}^{*} \mathrm{~L}_{1}{ }_{2}{ }_{2}, \Delta \mathrm{a}^{*}=\mathrm{a}^{*}{ }_{1}-\mathrm{a}_{2}{ }_{2} \text { and } \Delta \mathrm{b}^{*}=\mathrm{b}^{*}{ }_{1}-\mathrm{b}_{2}{ }_{2} .
\end{aligned}
$$

\subsection{Sensory acceptability}

The light and the traditional snack (flavored with $22 \%$ of vegetable hydrogenated fat) were evaluated at random, by a monadic presentation, on a nine-point hedonic scale (1-"dislike very much", 5- "indifferent" and 9- "like very much") ${ }^{25}$ for assessing each snack overall acceptability.

Forty snack consumers recruited among staff and students of the Faculty tested the snacks, without any knowledge of the formulation of the products. The judges were instructed to eat the snacks and rinse their palates with water between samples to minimize any residual effects. Four units of each sample were served in polythene packs that were blind-coded with three random numbers.

\subsection{Sensory preference}

Forty snack consumers recruited among staff and students of the Faculty tested both snacks. The light and traditional snacks underwent a preference comparison and purchase intention test. A blind comparison test was applied in order to assess which sample they enjoyed most. Immediately after that, an informed test was carried out, in which the samples were identified and the judges were informed about the snack composition. The aim of the second test was to evaluate the impact of composition information on preference. In both cases, the paired preference results were analyzed by binomial probability tables ${ }^{16}$.

A consumer opinion survey was conducted among these same judges in order to inquire which of the products they would buy.

\subsection{Statistical analysis}

The Student's t test was performed to compare the means of the texture and sensory acceptability data, taking a significance level of $5 \%$.

The data obtained were submitted to statistical analysis using the ORIGIN version 6.0 software (Origin, Microcal software, Inc., version: 6.0; Northampton, Massachusetts, USA. 2000).

\section{Results and discussion}

\subsection{Nutritional and fatty acids composition of snacks}

Table 1 shows a great variation in nutritional value between snacks available on the market. Similar values were observed only for products made by the same manufacturer, possibly because of the use of the same type and amount of food ingredients.

The caloric values for the snacks available on the market ranged from 398.3 to $682.5 \mathrm{kcal} .100 \mathrm{~g}^{-1}$ of the product. In all cases, low protein $\left(6.8 \pm 1.8 \mathrm{~g} .100 \mathrm{~g}^{-1}\right)$ and high lipid content ( $14.3 \pm 8.0$ g. $\left.100 \mathrm{~g}^{-1}\right)$ were observed. The products from manufacturer 4 presented the lowest lipid content (6\%), as shown in Table 1.

High amounts of saturated fatty acids were found in some products, with a large range in content (13.2-49.8\%). Only the products from manufacturer 4 presented values lower than $40 \%$. The products from manufacturer 4 presented the highest

Table 1. Comparative nutritional value and fatty acid composition of light snack and eleven snacks available on the market that were flavored with

\begin{tabular}{|c|c|c|c|c|c|c|c|c|c|c|c|c|c|}
\hline & \multirow{2}{*}{$\frac{\text { Manufacturer } 1}{\text { Cheese }}$} & \multicolumn{2}{|c|}{ Manufacturer 2} & \multicolumn{4}{|c|}{ Manufacturer 3} & \multicolumn{4}{|c|}{ Manufacturer 4} & \multirow[t]{2}{*}{ Mean \pm SD } & \multirow{2}{*}{$\begin{array}{l}\text { Light } \\
\text { snack }\end{array}$} \\
\hline & & Ham & Cheese & Cheese & $\begin{array}{l}\text { Cheese } \\
\text { spread }\end{array}$ & Pizza & $\begin{array}{l}\text { Cheese } \\
\text { spread }\end{array}$ & Bacon & Onion & Cheese & Barbecue & & \\
\hline $\begin{array}{l}\text { Caloric value } \\
\left(\mathrm{kcal}_{\left.100 \mathrm{~g}^{-1}\right)}\right.\end{array}$ & 482.5 & 662.5 & 682.5 & 440.0 & 440.0 & 440.0 & 398.3 & 398.3 & 398.3 & 398.3 & 398.3 & $467.2 \pm 105.2$ & 358 \\
\hline $\begin{array}{l}\text { Carbohydrate } \\
(\%)\end{array}$ & 65.0 & 105.0 & 110.0 & 60.0 & 60.0 & 60.0 & 79.0 & 79.0 & 79.0 & 79.0 & 79.0 & $77.7 \pm 17.0$ & 93.7 \\
\hline Protein (\%) & 5.0 & 10.0 & 10.0 & 5.0 & 5.0 & 5.0 & 7.0 & 7.0 & 7.0 & 7.0 & 7.0 & $6.8 \pm 1.8$ & 6.3 \\
\hline$\sum \mathrm{SFA}^{\mathrm{a}}$ & 43.7 & 46.8 & 47.0 & 49.8 & 48.3 & 47.5 & 17.5 & 17.7 & 19.6 & 13.2 & 17.3 & $33.5 \pm 15.9$ & - \\
\hline$\sum$ MUFA $^{\mathrm{b}}$ & 11.8 & 10.4 & 11.3 & 12.4 & 10.4 & 11.8 & 56.2 & 46.4 & 50.4 & 56.5 & 56.6 & $30.4 \pm 22.1$ & - \\
\hline$\sum$ PUFA $^{\mathrm{c}}$ & 37.1 & 41.8 & 41.2 & 34.1 & 40.7 & 41.4 & 23.3 & 31.9 & 23.6 & 23.1 & 23.2 & $32.8 \pm 8.2$ & - \\
\hline $\begin{array}{l}\sum \text { Trans fatty } \\
\text { acids }\end{array}$ & 1.2 & 1.0 & 0.5 & 0.7 & 0.7 & 0.7 & 3.0 & 2.7 & 5.6 & 3.0 & 2.9 & $2.0 \pm 1.6$ & - \\
\hline
\end{tabular}
hydrogenated vegetable fat. The samples of snacks available on the market were obtained from supermarkets in the city of São Paulo, 2003.

asaturated fatty acids; 'bonounsaturated fatty acids; and cpolyunsaturated fatty acids. 
content of monounsaturated fatty acids (greater than 45\%), while the other snacks presented about $10 \%$. Polyunsaturated fatty acids in cis configuration represented $33 \%$ of the fatty acid profile on average, and trans isomers presented a range from 0.5 to $5.6 \%$ (Table 1 ).

The results showed great variability between the snack brands on the market, probably because of the use of different kinds of hydrogenated vegetable fat. Various types of hydrogenated vegetable fat presenting a wide range of trans fatty acid composition are available on the Brazilian market ${ }^{8,24}$.

The snacks developed in this study presented 358 kcal. $100 \mathrm{~g}^{-1}$, which represented a reduction of 40.3 to $324.5 \mathrm{kcal} .100 \mathrm{~g}^{-1}$ in relation to the snacks available on the market. This caloric reduction (10-47.5\%) is justified by the claim "light snack" and "fat free", as it has only $0.03 \mathrm{~g}$ of fat in $100 \mathrm{~g}$ of food (maximum allowed $=0.5 \mathrm{~g} .100 \mathrm{~g}^{-1}$ ) according to the guidelines related to the use of nutrition claims in food labeling that are established by the Codex Alimentarius ${ }^{13}$ and adopted by certain countries, such as Brazil by the Brazilian Food Law $\mathrm{N}^{\circ}$ 27, January 13, $1998^{9}$.

\subsection{Shear strength}

No significant difference in shear strength was observed between the light snack $(27.2 \pm 6.3 \mathrm{~N})$ and the traditional snack $(26.1 \pm 6.1 \mathrm{~N})$.

\subsection{Color}

Table 2 shows the color CIE $\mathrm{L}^{*}, \mathrm{a}^{*}, \mathrm{~b}^{*}$ values of the light and traditional snacks. The results for color difference were $\Delta \mathrm{L}^{*}=-7.79 ; \Delta \mathrm{a}^{*}=-0.32 ; \Delta \mathrm{b}^{*}=3.79 ; \Delta \mathrm{E}=8.67$. The total color difference between the products $(\Delta \mathrm{E})$ was due mainly to the luminosity, which was greater in the traditional snack, because this was affected by the presence of fat.

Table 2. Comparative color values of light and traditional snacks (means \pm standard deviation, $\mathrm{n}=3$ ).

\begin{tabular}{lccc}
\hline \multicolumn{1}{c}{ Samples } & $\mathrm{L}^{*}$ & $\mathrm{a}^{*}$ & $\mathrm{~b}^{*}$ \\
\hline Light snack & $65.2 \pm 1.8$ & $5.1 \pm 0.3$ & $34.2 \pm 0.5$ \\
Traditional snack & $73.0 \pm 0.6$ & $5.4 \pm 0.3$ & $30.4 \pm 0.7$ \\
\hline
\end{tabular}

\subsection{Sensory acceptability and preference}

The light and traditional snacks presented high sensory acceptability, as shown in Figure 1. No significant difference between the acceptability of light snacks $(7.27 \pm 1.3$, mode $=7$, grades $\geq 7=82.5 \%)$ and traditional snacks $(7.52 \pm 0.96$, mode $=8$, grades $\geq 7=86.0 \%$ ) was observed.

The results obtained in both the blind and the informed test showed that the traditional snack was significantly preferred $(\mathrm{p}<0.05)$. When the judges were informed about snack fat content, the preference for the light snack went up from 22.5 to $30 \%$.

In the consumer opinion survey, when the interviewers were informed about snack composition, $75 \%$ of them said that they would buy the light snack instead of the traditional one. Spon-

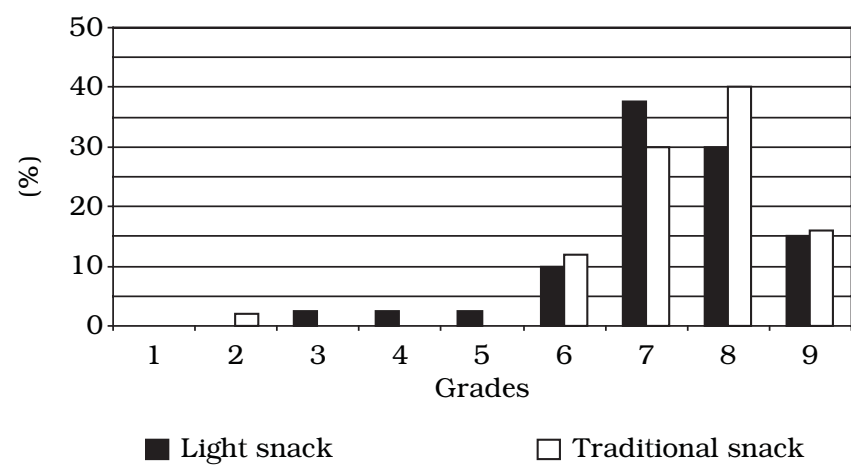

Figure 1. Percentage of grades attributed to light and traditional snacks.

taneous answers about the reasons for this preference showed that $56 \%$ would buy the new product for health-related reasons, $32 \%$ because it is as good as the traditional snack and $12 \%$ because the new product is better than the traditional snack.

\section{Conclusions}

Snacks are part of popular consumption habits, however the snacks available on the market present low protein and high lipid contents, with considerable amounts of saturated and trans fatty acids. Because of these factors, it is important to improve the nutritional composition of this food.

We have demonstrated that it is possible to use a non-fat flavoring solution as a snack flavor fixative agent. The new snack presented no significant differences in sensory acceptability when compared to the traditional product, and it significantly reduced calorie and lipid contents that justify the claim "light snack" and "fat free". The light snack has a promising market, particularly for health reasons.

\section{Acknowledgements}

The authors would like to thank FAPESP - Fundação de Amparo a Pesquisa do Estado de São Paulo for financial support, and Raí Ingredients Comercial Ltda, Norte Salineira S.A. - Indústria e Comércio and the National Starch \& Chemical Industrial for supplying the ingredient samples.

Light snacks have been patented by Universidade de São Paulo, Brazil - Patent no ${ }^{\circ}$ 0.502.694-6.

\section{References}

1. ALLISON, D. B. et al. Estimated intakes of trans fatty and other fatty acids in the US population. J. Am. Diet. Assoc., v. 99, n.2, p. 166-174, 1999.

2. AOAC - Association of Official Agricultural Chemists. (1975). Official Methods of Analysis. 12 ed. Washington: AOAC.

3. AOCS - American Oil Chemistry Society. Trans unsaturated fatty acids by capillary column gas chromatography. AOCS Recommended Practice Ch 2 a -94 .

4. AOCS - American Oil Chemistry Society. Determination of cis and trans fatty acids in hydrogenated and refined oils and fats by capillary GLC. AOCS Official Method Ce 1f-96. 
5. ARÊAS, J. A. G. Extrusion of food proteins. Crit. Rev. Food Sci. Nutr., v. 32, n. 4, p. 365-392, 1992.

6. ARÊAS, J. A. G. Interações moleculares do amido durante o processo de extrusão. Bol. SBCTA., v. 30, n. 1, p. 28-30, 1996.

7. ASCHERIO, A.; WILLETT, W. Health effects of trans fatty acids. Am. J. Clin. Nutr., v. 66, n.4, p. 1006-1010, 1997.

8. BLOCK J. M.; BARRERA - ARELLANO, D. Produtos hidrogenados no Brasil: isômeros trans, características físico-químicas e composição em ácidos graxos. Arch Latinoam Nutr., v. 44, n. 4 , p. 281-285, 1994

9. BRASIL. Portaria n. 27, de 13 de janeiro de 1998. Regulamento Técnico referente à Informação Nutricional Complementar. Diário Oficial da República Federativa do Brasil, Brasília, DF, 16 jan. 1998.

10. CAPRILES, V. D.; ARÊAS, J. A. G. Utilização de veículos não lipídicos na aromatização de snacks. In: Anais do V Simpósio Latino Americano de Ciência de Alimentos. 2003, Campinas: IRL Press.

11. CAPRILES, V. D.; SOARES, R. A. M.; ARÊAS, J. A. G. "Snack" light: desenvolvimento e análise da viabilidade nutricional e comercial. In: Anais do XIX Congresso Brasileiro de Ciência e Tecnologia de Alimentos. 2004, Recife: IRL Press.

12. CHAIR, E. B. F. et al. Position paper on trans fatty acids. Am. J. Clin. Nutr., v. 63, n. 5, p. 663- 670, 1996.

13. CODEX ALIMENTARIUS COMMISSION. Report of the twentyfourth session of the codex committee on food labeling - Alinorm 97/22. Appendix II - Guidelines for use of nutrition claims. Ottawa, Canada, 14-17 May 1996. Available at: <http://www. fao.org/docrep/meeting/005/W1715E/W1715E03.htm\#app2>. Accessed on: Jun 8, 2007.

14. ENIG, M. G. et al. Fatty Acid Composition of the Fat in Select Food Items with Emphasis on trans Components. JAOCS. v. 60, n. 10, p. 1788-1795, 1983.

15. FERREIRA, V. L. P. Princípios e aplicações da colorímetria em alimentos. Campinas: ITAL, 1981.

16. FERREIRA, V. L. P. et al. Análise sensorial: testes discriminativos e afetivos. Campinas: SBCTA, 2000.
17. GOMEZ, M. H.; AGUILERA, J. M. Changes in the starch fraction during extrusion cooking of corn. J. Food Sci., v. 48, n. 2, p. $378-381.1983$

18. HARPER, J. M. Extrusion texturization of foods. Food Tech., v. 40, n. 3, p.70-82, 1986.

19. HARTMAN, L.; LAGO, R. C. A. Rapid Preparation of fatty acid methyl esters from lipids. Lab. Pract. v. 22, n. 8, p. 475-476, 1973.

20. JUDD, J. T. et al. Dietary trans fatty acids: effects on plasma lipids and lipoproteins of healthy men and women. Am. J. Clin. Nutr., v. 59, n. 4, p. 861-868, 1994.

21. MARMER, W. N.; MAXWELL, R. J. Dry Column Method for the Quantitative Extraction and Simultaneous Class Separation of Lipids from Muscle Tissue. Lipids. v. 16, n. 5, p. 365-71, 1981.

22. MERCIER, C.; LINKO, P.; HARPER, J. M. Extrusion cooking. St. Paul, Minnesota, USA: American Association of Cereal Chemists, 1989.

23. MITCHELL, J. R.; ARÊAS, J. A. G. Structural in biopolymers during extrusion. In: KOKINI, J. L.; HO, C. T.; KARWE, M. V. Food Extrusion Science and Technology. New York: Marcel Dekker; 1992. p. 345-360.

24. SOARES, L. M. V; FRANCO, M. R. B. Níveis de trans isômeros e composição de ácidos graxos em margarinas nacionais e produtos hidrogenados semelhantes. Ciên. Tecnol. Aliment., v. 10, n. 1, p. 57-71, 1990.

25. STONE, H.; SIDEL, J. L. Sensory Evaluation Practices. London: Academic Press. 1985.

26. SUBBAIAH, P. V.; SUBRAMANIAN, V. S.; LIU, M. Trans unsaturated fatty acids inhibit lecithin: cholesterol acyltransferese and alter its positional specificity. J. Lipid Res. v. 39, n. 7, p. 1438-1447, 1998.

27. TAVELLA, M. et al.Trans fatty acid content of a selection of foods in Argentina. Food Chem., v. 69, n. 2, p. 209-213, 2000.

28. WATT, B.; MERRILL, A. L. Composition of foods: raw, processed, prepared. Washington DC: Consumer and Food Economics Research. Division/ Agricultural Service. (Agriculture Handbook, 8), 1963. 